\title{
A low-fibronectin-binding mutant of Staphylococcus aureus 879R4S has In918 inserted into its single fnb gene
}

\author{
C. Greene, ${ }^{1}$ P. E. Vaudaux, ${ }^{2}$ P. Francois, ${ }^{2}$ R. A Proctor, ${ }^{3}$ D. McDevitt ${ }^{1} \dagger$ and \\ T. J. Foster ${ }^{1}$
}

Author for correspondence: T. J. Foster. Tel: +353 1 7022014. Fax: + 35316799294. e-mail: Tfoster@mail.tcd.ie

\footnotetext{
1 Microbiology Department, Moyne Institute of Preventive Medicine, Trinity College, Dublin 2, Ireland

2 Division of Infectious Diseases, Hopital Cantonal Universitaire, Geneva, Switzerland

3 Department of Medical Microbiology, University of Wisconsin, Madison, WI USA
}

\begin{abstract}
A low-fibronectin-binding mutant of Staphylococcus aureus strain 879R4SSp generated by transposon Tn918 mutagenesis is attenuated in a rat endocarditis model (J. M. Kuypers \& R. A. Proctor, 1989, Infect Immun 57. 2306-2312). PCR and Southern hybridization analysis with primers and probes, respectively, for the fnbA and $f n b B$ genes of strain 8325-4 showed that strain 879R4SSp possesses a single fnb gene which is homologous to fnbA. This was confirmed by sequencing 41 bp of 5' non-coding and 237 bp of 5' coding DNA, which showed $97 \%$ base identity to fnbA. Southern hybridization and sequencing showed that Tn918 was inserted 41 bp 5' to fnbA in the mutant 879R4SSp/1536, between the promoter and initiation codon. Reduced adherence of the mutant to surface-bound fibronectin correlated with lower expression of a $180 \mathrm{kDa}$ wall-associated fibronectin-binding protein.
\end{abstract}

Keywords: Stapbylococcus aureus, fibronectin-binding protein, endocarditis, adherence, virulence

\section{INTRODUCTION}

The ability of pathogens to attach to host cells or tissues is an important step in the initiation of infection. Stapbylococcus aureus can adhere to host matrix proteins such as fibrinogen, collagen, laminin and vitronectin (Boden \& Flock, 1989; Chhatwal et al., 1987; Holderbaum et al., 1987; Lopes et al., 1985; McDevitt et al., 1994; Speziale et al., 1986). The organism also binds to fibronectin, both in solution and on surfaces (Bozzini et al., 1992). The fibronectin-binding activity has been shown to be due to high-molecular-mass cell-wallassociated proteins (fibronectin-binding proteins, FnBPs). Strain 8325-4 expresses two distinct but related FnBPs called FnBPA and FnBPB (Jonsson $e t$ al., 1991 ; Signas $e t$ al., 1989). These are encoded by closely linked but separately transcribed fnb genes (Greene et al., 1995) (Fig. 1 ), both of which must be inactivated to eliminate bacterial interactions with fibronectin.

†Present address: Institute of Biosciences and Technology, Texas Medical Centre, 2121 West Holcombe Boulevard, Houston, TX 77030-3303, USA.

Abbreviations: FnBP, fibronectin-binding protein; PMMA, poly(methyl methacrylate).

The EMBL accession number for the fnbA sequence reported in this paper is $X 95848$.
The FnBPs are composed of distinct domains. Region A is the most divergent (approximately $45 \%$ residue identity). The $B$ region of FnBPA (repeats of 30 residues) is lacking altogether in FnBPB. In contrast, regions $C, D, W$ and $M$ are very similar. Regions $W$ and $M$ are required for sorting of the FnBPs to the surface and for attachment to the cell wall (Navarre \& Schneewind, 1994; Schneewind et al., 1993). The ligand-binding activity is located in region D (Raja et al., 1990; Signas et al., 1989) which is composed of three repeats of 38 residues (D1-D3) plus one incomplete repeat. Each D repeat can bind fibronectin. The minimum fibronectin-binding region occurs within residues 15-36 (McGavin et al., 1991).

FnBPs have been isolated from a number of streptococcal species (Hanski \& Caparon, 1992; Lindgren et al., 1992; Speziale et al., 1986). Comparison of the amino acid sequences of the fibronectin-binding domains of staphylococcal and streptococcal FnBPs has identified a core fibronectin-binding sequence EDT/S-(X9,10)-GG(X3,4)-I/VDF (McGavin et al., 1993).

A low-fibronectin-binding mutant of strain 879R4SSp caused by insertion of transposon $\operatorname{Tn} 918$ was isolated by Kuypers \& Proctor (1989) but the insertion site was not characterized. The mutant, S. aureus $879 \mathrm{R} 4 \mathrm{SSp} / 1536$, was shown to be significantly less virulent in a rat model for 
endocarditis suggesting that attachment to fibronectin is an important step in the pathogenesis of this disease.

In this study the structure of the $f n b$ locus of strain $879 R 4 S S p$ was analysed and compared to that of strain 8325-4. The insertion site of Tn 918 was mapped by Southern hybridization and identified precisely by sequencing a PCR-amplified junction fragment between Tn 918 and the fnb gene.

\section{METHODS}

Bacterial strains and plasmids. These are listed in Table 1. Strain 879 R4S and the Tn918 mutant $879 R 4$ S/1536 were used for adherence and protein analysis while the spectinomycinresistant derivatives $879 \mathrm{R} 4 \mathrm{SSp}$ and $879 \mathrm{R} 4 \mathrm{SSp} / 1536$ were used for DNA analysis.

Bacterial growth. $S$. aureus strains were grown routinely in trypticase soy broth or agar, and Mueller-Hinton broth was used to grow cultures for adherence assays and protein analysis. Escherichia coli strains harbouring plasmids were grown in Lbroth and L-agar (Miller, 1972) containing ampicillin at $100 \mu \mathrm{g}$ $\mathrm{ml}^{-1}$.

Manipulation of DNA. DNA-modifying enzymes were purchased from New England Biolabs and were used according to the manufacturer's instructions. DNA manipulations were performed using standard procedures (Ausubel et al., 1987; Sambrook et al., 1989). DNA hybridization was performed by the method of Southern (1975). S. aureus genomic DNA was purified by the method of Lindberg et al., (1972). Probe DNA was labelled with $\left[\alpha-{ }^{32} \mathrm{P}\right] \mathrm{dATP}$ by the random primer method using the Prime-A-Gene kit (Promega). Probe A was a $1.2 \mathrm{~kb}$ fragment corresponding to bases 147-1344 of the fnb $A$ gene of strain 8325-4. It was isolated from plasmid pFR040 by cleavage with EcoRI and XbaI. Probe B corresponded to bases 113-1635 of the $f n b B$ gene of $8325-4$. This fragment was released from plasmid pFR060 with $A c c$ I. One $A c c$ I site is located within the multiple cloning site of pUC18 and the other in the $f n b B$ gene. These probes comprise sequences that are specific for $f n b A$ and $f n b B$, respectively. Probe $C$ was isolated from pFR001 by cutting with $S p b I$ (site in pBR322) and EcoRI (site in fnb $A$ gene). It carries $1 \mathrm{~kb}$ of DNA $5^{\prime}$ to $f n b A$ and the first $147 \mathrm{bp}$ of the open reading frame. Sequencing was carried out with fluorescently labelled SP6 and T7 primers using an Applied Biosystems automated sequencer.

Primers that specifically amplified $f n b A(330-1674$ bp) and $f n b B$ (328-1489 bp) by recognizing unique sequences in region $A$ of each gene were described by Greene et al. (1995).

Amplification of a Tn918-fnb junction fragment. A Tn $918-f n b$ junction fragment from $S$. aureus $879 \mathrm{R} 4 \mathrm{SSP} / 1536$ was amplified from chromosomal DNA using Vent DNA polymerase and the oligonucleotides 5'-GACGGTACCTGAGTGGTTTTGACC$3^{\prime}$ (forward 3) or 5'-GCAGGTACCATGACGCTGAACTAT$3^{\prime}$ (forward 4), corresponding to the right-hand and left-hand ends of $\operatorname{Tn} 916$, respectively (Clewell et al., 1988) and 5'. CGTGGTACCTGTTGCGTTATATGATTG-3' (reverse 3) corresponding to bases 219-238 of the $f n b A$ gene of $S$. aureus 8325-4. All primers had a $9 \mathrm{bp}$ extension with a $K p n I$ site (underlined) incorporated into their $5^{\prime}$ ends. PCR reaction

Table 1. Bacterial strains and plasmids

\begin{tabular}{|c|c|c|c|}
\hline Strain or plasmid & $\begin{array}{l}\text { Relevant genotype or } \\
\text { [marker*] }\end{array}$ & Relevant properties & Source or reference \\
\hline \multicolumn{4}{|l|}{ Strains } \\
\hline \multicolumn{4}{|l|}{ E. coli } \\
\hline TB1 & $\begin{array}{l}\text { ara thi rpsL bsd }\left(\mathrm{r}_{\mathrm{k}}^{-} \mathrm{m}_{\mathrm{k}}^{+}\right) \\
\quad \Delta(\text { lac-pro } A B)[\phi 80 \mathrm{~d} l a c \Delta(\operatorname{lac} Z) \mathrm{M} 15]\end{array}$ & & Yanisch-Perron et al. (1985) \\
\hline \multicolumn{4}{|l|}{ S. aureus } \\
\hline 879R4S & $f n b A^{+}$ & Restriction negative & Kuypers \& Proctor (1989) \\
\hline $879 R 4 S S p$ & $f n b A^{+}$ & $\begin{array}{l}\text { Restriction negative, spectinomycin } \\
\text { resistant }\end{array}$ & Kuypers \& Proctor (1989) \\
\hline $879 R 4 S / 1536$ & fnb $A:: \operatorname{Tn} 918$ & $\begin{array}{l}\text { Tn } 918 \text { mutant of } 879 \mathrm{R} 4 \mathrm{~S} \text { defective } \\
\text { in fibronectin binding }\end{array}$ & Kuypers \& Proctor (1989) \\
\hline $879 \mathrm{R} 4 \mathrm{SSp} / 1536$ & fnb $A:: \operatorname{Tn} 918$ & $\begin{array}{l}\text { Tn918 mutant of } 879 \mathrm{R} 4 \mathrm{SSp} \\
\text { defective in fibronectin binding. } \\
\text { Transduced from } 879 \mathrm{R} 4 \mathrm{~S} / 1536\end{array}$ & Kuypers \& Proctor (1989) \\
\hline $8325-4$ & $f n b A^{+} f n b B^{+}$ & 8325 cured of prophages & Novick (1963) \\
\hline \multicolumn{4}{|l|}{ Plasmids } \\
\hline pFR001 & $A p^{r}$ & $\begin{array}{l}f n b A^{+} f n b B \text { lacking } 1 \cdot 1 \mathrm{~kb} \text { of } 3^{\prime} \\
\text { sequence }\end{array}$ & Signas et al. (1989) \\
\hline pFR040 & $A p^{r}$ & $\begin{array}{l}3.5 \mathrm{~kb} \text { insert of } f n b A \text { lacking } 147 \mathrm{bp} \\
\text { of } 5^{\prime} \text { sequence }\end{array}$ & Jonsson et al. (1991) \\
\hline pFR060 & $A p^{r}$ & $\begin{array}{l}3.2 \mathrm{~kb} \text { insert of } f n b B \text { lacking } 113 \mathrm{bp} \\
\text { of } 5^{\prime} \text { sequence }\end{array}$ & Jonsson et al. (1991) \\
\hline pGEM-7Zf(+) & $A p^{r}$ & Cloning vector & Promega \\
\hline
\end{tabular}

*Ap ${ }^{r}$, ampicillin resistance. 

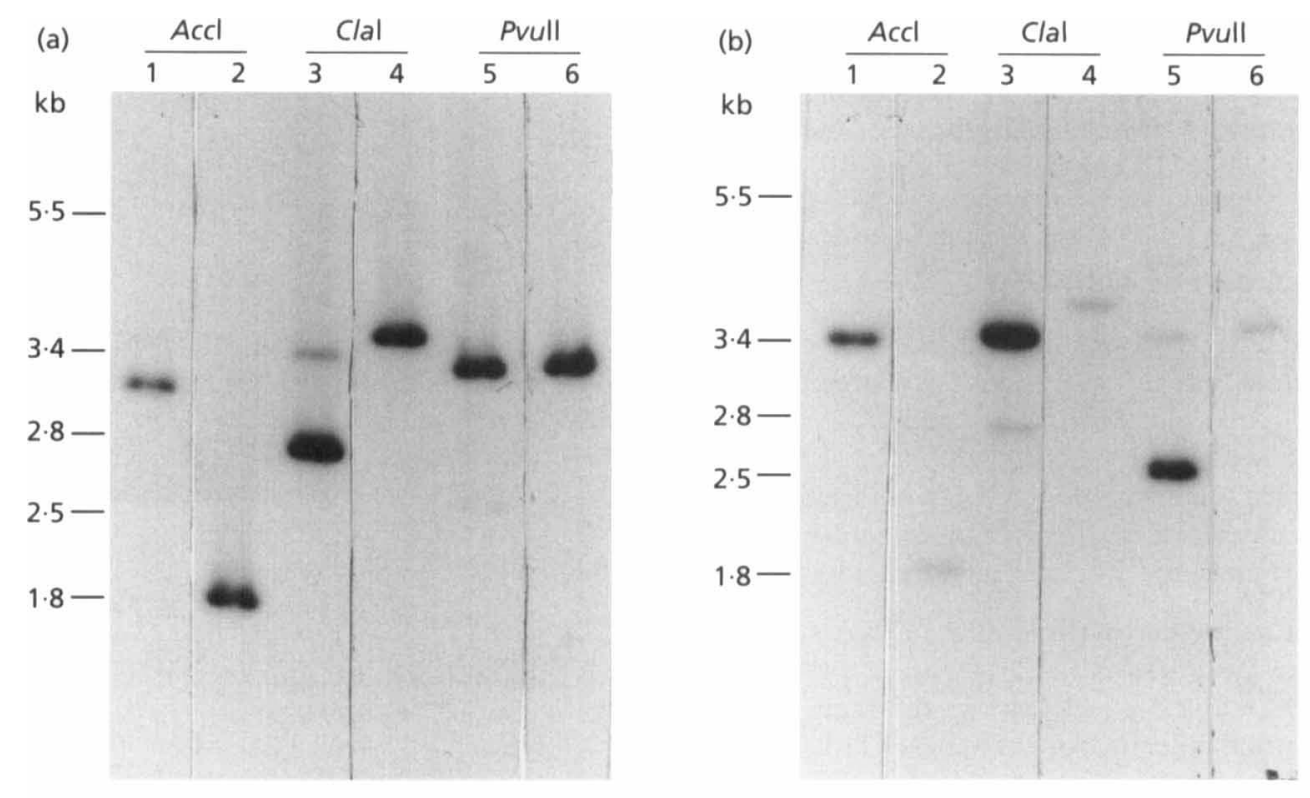

(c)

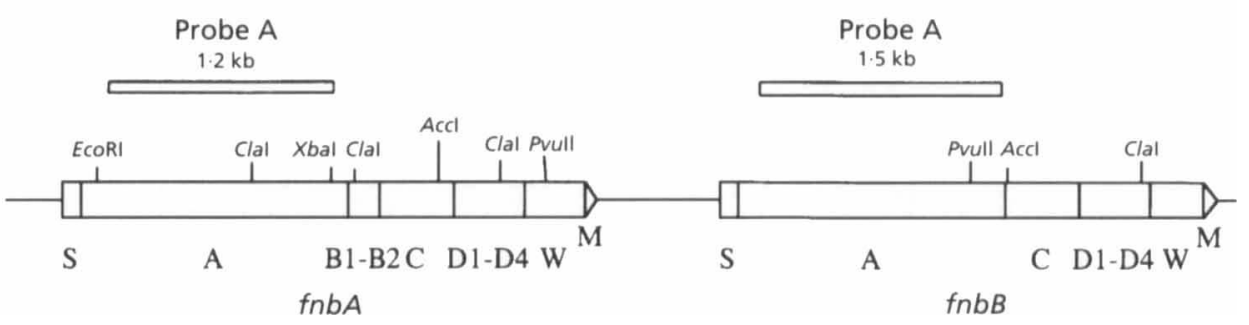

Fig. 1. Southern hybridization analysis of $S$. aureus strains $8325-4$ and $879 R 4 S S p$. (a,b) Chromosomal DNA of strains 8325-4 (lanes 1, 3 and 5) and 879R4SSp (lanes 2, 4 and 6) was cut with Accl (lanes 1 and 2), Clal (lanes 3 and 4) or Pvull (lanes 5 and 6), electrophoresed in a $0.8 \%$ agarose gel, transferred to a nylon membrane and hybridized with (a) a $1.2 \mathrm{~kb}$ probe specific for the fnbA gene of 8325-4 or (b) a $1.5 \mathrm{~kb}$ probe specific for the $f n b B$ gene of 8325-4. (c) Map of the fnb locus of 8325-4 and probes A and B. Regions marked S, A, B, C, D, W and M are domains in the FnBPA and FnBPB proteins. The $3056 \mathrm{bp}$ fnbA gene is separated from the $2823 \mathrm{bp}$ fnbB gene by a 682 bp intragenic region.

mixtures contained $10 \mathrm{mM} \mathrm{KCl}, 10 \mathrm{mM}\left(\mathrm{NH}_{4}\right)_{2} \mathrm{SO}_{4}, 20 \mathrm{mM}$ Tris/ $\mathrm{HCl}$ (pH 8.8), $2 \mathrm{mM} \mathrm{MgSO}, 0 \cdot 1 \%$ Triton X-100, $10 \mathrm{ng}$ template DNA (S. aureus 879R4SSp/1536 chromosomal DNA), $2 \mathrm{mM}$ of each dNTP, $200 \mathrm{mM}$ forward and reverse primers, and 2 units Vent DNA polymerase in a $100 \mathrm{ml}$ volume. Cycling parameters began with an initial denaturing step of $94^{\circ} \mathrm{C}$ for $7 \mathrm{~min}$, followed by 30 cycles of $94^{\circ} \mathrm{C}$ for $1 \mathrm{~min}, 45^{\circ} \mathrm{C}$ for $1 \mathrm{~min}$ and $72{ }^{\circ} \mathrm{C}$ for $1 \mathrm{~min}$, and ended with a $10 \mathrm{~min}$ extension step at $72{ }^{\circ} \mathrm{C}$.

Adhesion to fibronectin-coated coverslips. Purified human fibronectin (Chemicon) was dissolved in PBS [0.145 M NaCl, $0 \cdot 15 \mathrm{M}$ sodium phosphate (ph $7 \cdot 3$ ); oxoid] at $1 \mathrm{mg} \mathrm{ml}^{-1}$ and stored at $-70^{\circ} \mathrm{C}$. The concentration was measured spectrophotometrically using $A_{280} 1 \cdot 28$. The attachment properties of $S$. aureus strains were measured using a previously described adhesion assay with poly(methyl methacrylate) (PMMA) coverslips coated in vitro with purified fibronectin (Vaudaux et al., 1984, 1995). To optimize absorption of fibronectin from concentrations below $1 \mu \mathrm{g} \mathrm{m} l^{-1}$, the PMMA coverslips were precoated with gelatin $\left(1 \mathrm{mg} \mathrm{ml}^{-1}\right)$. After rinsing in PBS, they were incubated for $60 \mathrm{~min}$ at $37^{\circ} \mathrm{C}$ with low concentrations (ranging from $0 \cdot 125$ to $1 \mu \mathrm{g} \mathrm{ml}^{-1}$ ) of fibronectin followed by rinsing in PBS. PMMA surfaces were shown to be coated in a dose-dependent manner with fibronectin ranging from 24 to $92 \mathrm{ng}$ per coverslip (Vaudaux et al., 1993). The adhesion characteristics of $S$. aureus strains were evaluated by incubating coverslips with $4 \times 10^{6}$ c.f.u. washed exponential-phase cells, radiolabelled with $\left[{ }^{3} \mathrm{H}\right]$ thymidine during growth in MuellerHinton broth.

SDSPAGE and Western affinity blotting. Bacteria were grown to stationary phase without shaking in Mueller-Hinton broth at $37^{\circ} \mathrm{C}$. Cells were harvested by centrifugation at $5000 \mathrm{~g}$ and washed twice in PBS. Bacteria were lysed in $1.5 \mathrm{ml}$ PBS containing lysostaphin (AMBI; $\left.20 \mu \mathrm{g} \mathrm{m}^{-1}\right)$, DNase $(10 \mu \mathrm{g}$ $\left.\mathrm{ml}^{-1}\right)$, aprotinin $(78 \mathrm{nM})$, benzamidine $(0.83 \mathrm{mM})$, iodoacetamide $(1 \mathrm{mM})$, leupeptin $(1.1 \mathrm{mM})$, pepstatin $\mathrm{A}(0.7 \mathrm{mM})$, phenylmethanesulfonyl fluoride $(0.25 \mathrm{mM})$ and dithiothreitol ( $1 \mathrm{mM}$ ) (all from Sigma) for $15 \mathrm{~min}$ at $37^{\circ} \mathrm{C}$. The lysate was centrifuged at $5000 \mathrm{~g}$ for $10 \mathrm{~min}$ and the supernatant retained. The protein concentration was determined by the BCA method (Pierce) and adjusted to $3 \mathrm{mg} \mathrm{ml}^{-1}$ with PBS. Aliquots were boiled in Laemmli buffer (Laemmli, 1970) and separated by SDS-PAGE using $6 \%(\mathrm{w} / \mathrm{v})$ acrylamide. Proteins were transferred to an Immobilon membrane (Millipore) using a liquid transblot system (BioRad). The membrane was blocked in $10 \mathrm{mM}$ Tris/ $\mathrm{HCl}(\mathrm{pH} 8 \cdot 0), 500 \mathrm{mM} \mathrm{NaCl}, 0 \cdot 1 \%$ Tween 20 (Fluka) (TBST) containing 5\% (w/v) skimmed milk and incubated with pure human fibronectin $\left(30 \mu \mathrm{g} \mathrm{ml}^{-1}\right.$ in TBST). The membrane was rinsed several times in TBST and incubated 
with monoclonal antibody mAb-1936 raised against the $\mathrm{N}$ terminus of fibronectin $(1: 5000$, Chemicon) followed by peroxidase-conjugated anti-mouse $\operatorname{IgG}(1: 5000$; Amersham). Detection was by enhanced chemiluminescence (Amersham).

\section{RESULTS}

\section{The fnb locus of S. aureus 879R4SSp}

S. aureus strains 8325-4 and Newman have two closely linked chromosomal genes, $f n b A$ and $f n b B$, encoding fibronectin-binding proteins (Jonsson et al., 1991; Signas et al., 1989). To investigate the structure of the fnb locus of strain 879R4SSp, genomic DNA of this strain and strain 8325-4 was cleaved with restriction enzymes Acc I, $C l a \mathrm{I}$ and PvuII and analysed by Southern hybridization.

Fig. 1(a) shows blots probed with labelled DNA specific for the fnb $A$ gene of $S$. aureus 8325-4 (bases 147-1344 spanning region $A$ ) while Fig. 1 (b) shows the same DNA probed with a fragment specific for $f n b B$ (bases 113-1635). With the $f n b A$ probe signals of similar intensity occurred in each lane suggesting that $879 \mathrm{R} 4 \mathrm{SSp}$ has an $\mathrm{fnb}$ gene which is related to $f n b A$ of $8325-4$. In contrast, the $f n b B$ specific probe hybridized only weakly to 879R4SSp DNA. Furthermore, the weakly hybridizing bands were of the same size as those which hybridized to the $f n b A$ probe whereas for each enzyme a different sized fragment reacted in the 8325-4 samples. Also, in each sample of 8325-4 DNA probed with the $f n b A$-specific probe a second faint band which was the same size as the more intense band in the corresponding reaction with the $f n b B$-specific probe was seen. Similarly, a faint band occurred in the $f n b B$ probed samples which corresponded in size to the major band in the $f n b A$ reactions. This is due to slight crossreaction occurring between the $f n b A$ probe and the $f n b B$ gene and vice versa. Second fainter bands were not seen with $879 \mathrm{R} 4 \mathrm{SSp}$ DNA and the $f n b A$ probe. These data strongly suggest that $879 \mathrm{R} 4 \mathrm{SSp}$ has a single $f n b$ gene which is closely related to $f n b A$ of $8325-4$.

Further restriction mapping experiments (not shown) revealed some conserved restriction sites (Pst 1 and EcoRI) within the $f n b A$ genes of 879R4SSp and 8325-4. However, several polymorphic sites including ClaI sites were noted (see Fig. 3)

Genomic DNA of strain 879R4SSp was amplified by PCR with primers that specifically recognize unique sequences in region $A$ of $f n b A$ and $f n b B$ of strain 8325-4 (Greene $e t$ al., 1995). The $f n b A$-specific primers gave a fragment of $1.3 \mathrm{~kb}$ in both $8325-4$ and $879 \mathrm{R} 4 \mathrm{SSp}$ (Fig. 2, lanes 1 and $3)$. In contrast the $f n b B$-specific primers amplified a fragment of about $1 \mathrm{~kb}$ in $8325-4$ but did not amplify a fragment from 879R4SSp (Fig. 2, lanes 2 and 4), which also suggests that the $f n b B$ gene is absent in this strain.

\section{Analysis of the Tn918 insertion in strain 879R4SSp/1536}

Kuypers \& Proctor (1989) showed that there is a single Tn 918 insertion in the low-fibronectin-binding strain $879 R 4 S S p / 1536$. They transduced the Tn918 insertion

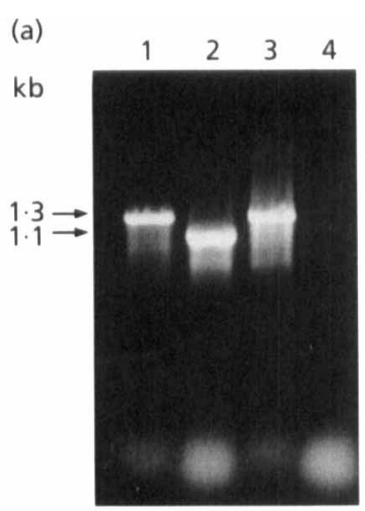

(b)

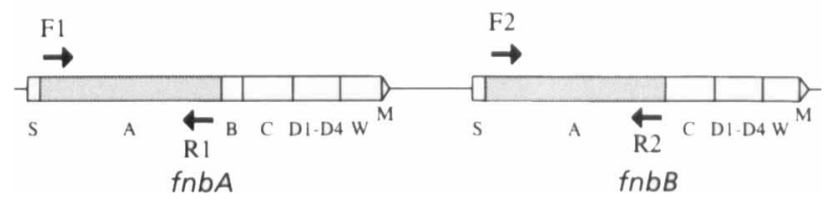

Fig. 2. $P C R$ analysis with $f n b A$ - and $f n b B$-specific primers. (a) Genomic DNA from S. aureus strains 8325-4 (lanes 1 and 2) and 879R4SSp (lanes 3 and 4) was amplified with fnbA-specific (lanes 1 and 3) or fnbB-specific (lanes 2 and 4) primers. (b) Map showing positions of the $f n b A$ - and $f n b B$-specific primers in the 8325-4 fnb locus.

from the parental strain $879 \mathrm{R} 4 \mathrm{~S}$ to the spectinomycinresistant derivative $879 \mathrm{R} 4 \mathrm{SSp}$ and showed by Southern hybridization that the transposon was located in the same sized EcoRI fragment, indicating that $\operatorname{Tn} 918$ was acquired by homologous recombination. To determine if the $16.8 \mathrm{~kb}$ transposon Tn918 (Clewell et al., 1985) is located in the $f n b A$ gene, genomic DNA of strains 879R4SSp and 879R4SSp/1536 was analysed by Southern hybridization. DNA was cleaved with EcoRI, HindIII, ClaI and PstI and hybridized with probe A from the $f n b A$ gene of 8325-4. For EcoRI, ClaI and Pst I there were no differences in the sizes of the hybridizing fragments between the wild-type and the mutant (data not shown). However, a large ( $>15 \mathrm{~kb}$ ) HindIII fragment in $879 \mathrm{R} 4 \mathrm{SSp}$ DNA was about $2 \mathrm{~kb}$ larger in the mutant. As Tn918 carries a HindIII site, this must be the right junction fragment of Tn918 and the $>15 \mathrm{~kb}$ chromosomal HindIII fragment. It should also be noted that the single ClaI site in the $879 \mathrm{R} 4 \mathrm{SSp} f n b A$ gene is quite close to the $5^{\prime}$ end of the gene and is either very close to the end of the region covered by probe A, or outside it. This explains why the ClaI fragment hybridizing with probe A did not change in the mutant.

DNA was then analysed with probe $C$ corresponding to $5^{\prime}$ non-coding DNA and the first $147 \mathrm{bp}$ of $f n b A$. The hybridization pattern of the parent and mutant samples differed for each enzyme tested (Fig. 3). For EcoRI and ClaI the 879R4SSp fragments of $5.5 \mathrm{~kb}$ and $4 \mathrm{~kb}$, respectively, had increased to $>15 \mathrm{~kb}$, presumably due to the insertion of Tn918. In the case of HindIII, two bands hybridized to the probe in the $879 \mathrm{R} 4 \mathrm{SSp} / 1536$ sample. The larger corresponds to the single larger fragment seen 


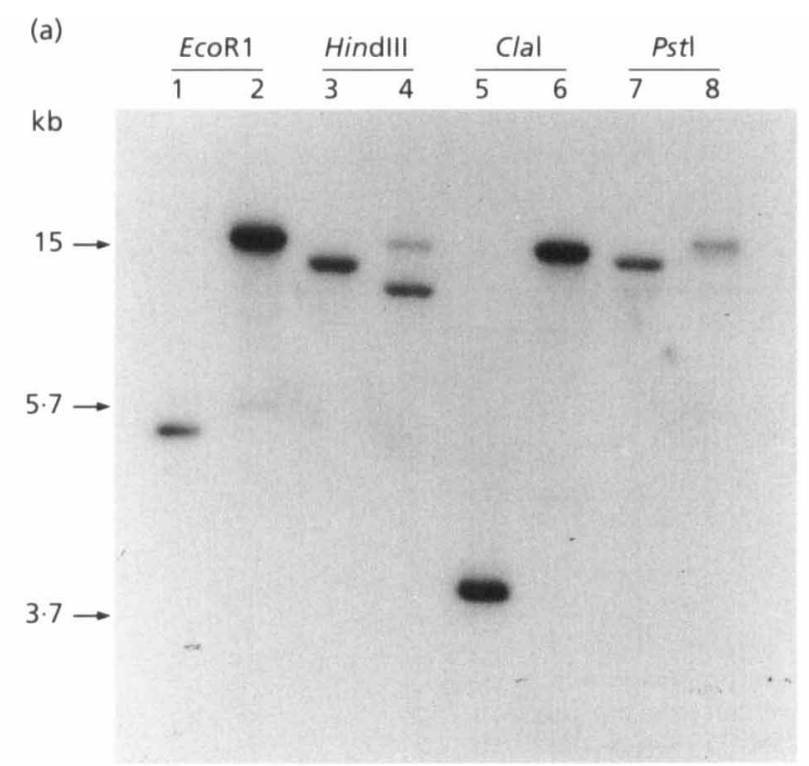

(b)
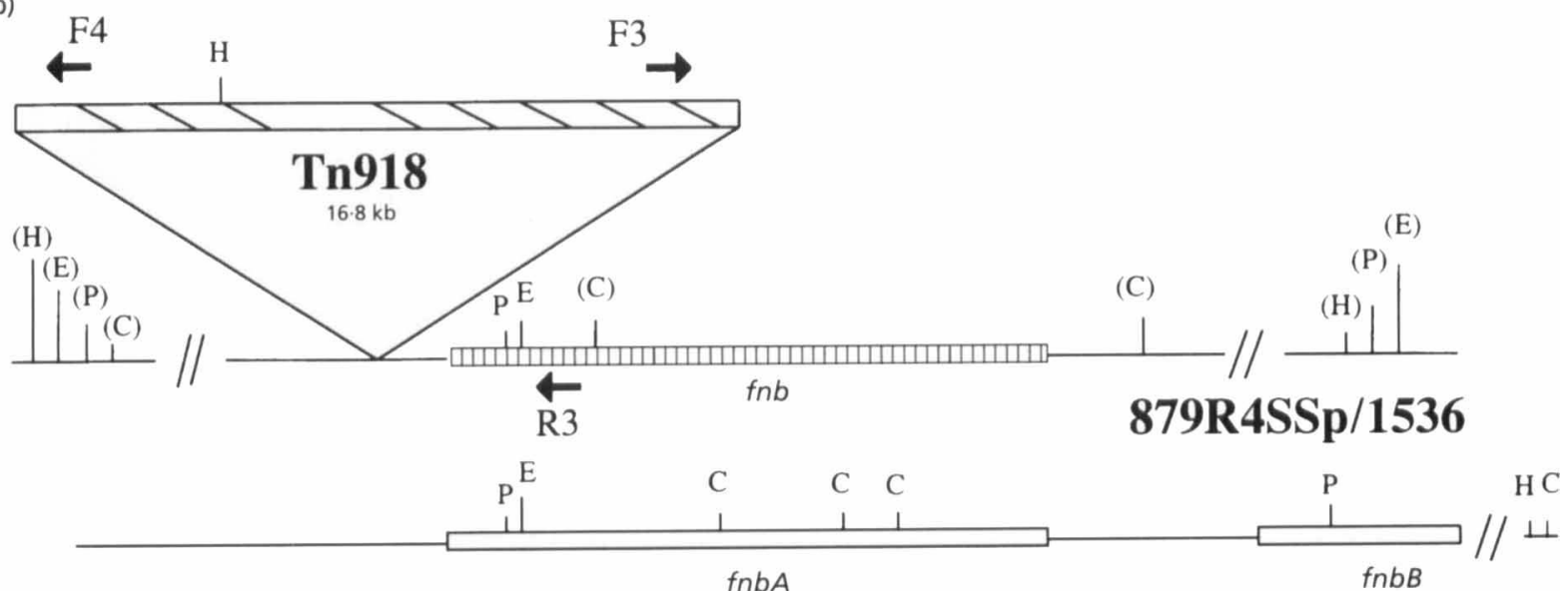

8325-4

Probe $C$

$1.1 \mathrm{~kb}$

Fig. 3. Southern hybridization analysis of the insertion site of Tn918 in S. aureus strain 879R4SSp/1536. (a) Chromosoma DNA of 879R4SSp (lanes 1, 3, 5 and 7) and 879R4SSp/1536 (lanes 2, 4, 6 and 8) was cut with EcoRI (lanes 1 and 2), HindIII (lanes 3 and 4), Clal (lanes 5 and 6) or Pstl (lanes 7 and 8), electrophoresed in a $0.8 \%$ agarose gel, transferred to a nylon membrane and hybridized with probe $C$, a $1.1 \mathrm{~kb}$ fragment corresponding to the $5^{\prime}$ flanking region and the first $147 \mathrm{bp}$ of fnbA of S. aureus 8325-4. (b) Map of the predicted structure of the fnb locus of strain 879R4SSp/1536. The PCR primers used to amplify the Tng18-fnb junction fragment are indicated. Restriction sites deduced from mapping experiments are shown in parentheses. C, Clal; P, Pstl, E, EcoRI; H, HindIII.

with probe $A:$ Tn 918 has a single HindIII site and probe $\mathrm{C}$ must hybridize to DNA flanking both the left-hand and right-hand ends of the transposon. ( $\operatorname{Tn} 918$ does not have EcoRI, ClaI or Pst I sites so only a single larger fragment hybridized in the mutant samples.) A Pst I fragment of $879 \mathrm{R} 4 \mathrm{SSp}$ of about $15 \mathrm{~kb}$ was also significantly larger in the mutant, but it was not possible to measure fragment sizes accurately under the conditions used. It was concluded that $\mathrm{Tn} 918$ had probably inserted into non-coding
DNA $5^{\prime}$ to the $f n b A$ gene or within the open reading frame very close to the $5^{\prime}$ end.

\section{Mapping the Tn918 insertion site by PCR and DNA sequencing}

To map precisely the site of the $\operatorname{Tn} 918$ insertion in the fnb $A$ locus of $879 \mathrm{R} 4 \mathrm{SSp} / 1536$, a junction fragment between $T n 918$ and the $f n b A$ gene was amplified by PCR. 


\section{$-35$}

GGTACC TGAGTGGTTM TAACCTTAAT AAAGTGTGAT AAGTCCAGTT

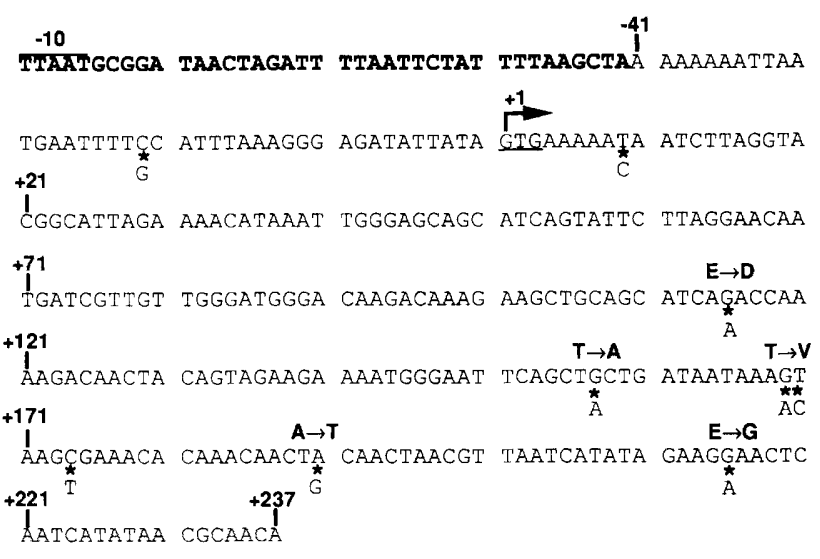

Fig. 4. Sequence of the Tn918-fnb junction fragment of $S$. aureus strain $879 R 45 S p / 1536$. A fragment carrying the junction of $\mathrm{Tn} 918$ and the $f n b A$ gene of $879 \mathrm{R} 4 \mathrm{SSp} / 1536$ was amplified by $\mathrm{PCR}$, cloned into pGEM-7Zf( + ) and sequenced. Bold type denotes Tn918 sequence. Plain type denotes $f n b A$ sequence. Differences between the 879R4SSp and 8325-4 fnbA genes are shown, as well as changes in the FnBPA amino acid sequences.

Since the orientation of Tn918 was not known, PCR forward primers were designed to coincide with DNA $74 \mathrm{bp}$ inside either end of the transposon. A single reverse primer corresponded to bases 219-238 of the 8325-4 fnb $A$ gene (Fig. 3)

A product of 370 bp was amplified by primers F3 and R3, while primers F4 and R3 did not yield a product. The fragment was sequenced and comparison with the 8325-4 fnb $A$ gene showed that $\operatorname{Tn} 918$ was located between bases -41 and $-425^{\prime}$ to the $f n b A$ structural gene (Fig. 4). Although the $f n b A$ coding sequence was not disrupted by the transposon, expression of the gene is likely to be affected because transcription from the $f n b A$ promoter, located at bases -85 to -57 in strain $8325-4$ (Greene et al., 1995) would be prevented. A fragment of the same size was amplified from the spectinomycin-sensitive strain 879R4S/1536 (data not shown) which demonstrates that the transposon is located at the same site in both strains.

The $f n b A$ gene of strain 879 R 4 SSp was $96.8 \%$ identical to $f n b A$ of $8325-4$ in the 41 bp of $5^{\prime}$ non-coding sequence and in the coding sequences between bases 1 and 237. There were only nine mismatches over a stretch of $278 \mathrm{bp}$. Eight base differences occurred in the coding sequence; two were silent while the other six caused five amino acid subsitutions (Fig. 4).

\section{Expression of fibronectin-binding proteins}

Western ligand affinity blotting was performed on proteins released from the cell walls of strains $879 \mathrm{R} 4 \mathrm{~S}$ and the mutant $879 \mathrm{R} 4 \mathrm{~S} / 1536$ (Fig. 5). A single reactive protein of about $180 \mathrm{kDa}$ was observed. The native form of FnBPA of 8325-4 had a predicted molecular mass of $108 \mathrm{kDa}$ but was observed to migrate in SDS-PAGE at about $200 \mathrm{kDa}$ (Greene et al., 1995). The intensity of the

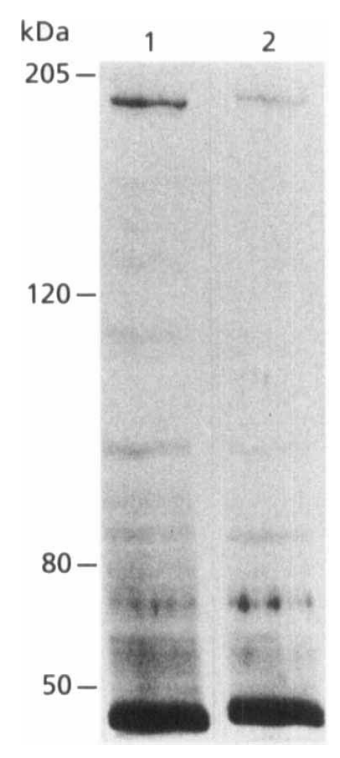

Fig. 5. Western ligand affinity blotting analysis of proteins extracted by lysostaphin treatment from the cell wall of $S$. aureus strains 879R4S (lane 1) and 879R4S/1536 (lane 2).

$180 \mathrm{kDa}$ protein in the $879 \mathrm{R} 4 \mathrm{~S} / 1536$ sample was greatly reduced, which is consistent with the Tn918 insertion being located $5^{\prime}$ to, and not within, the $f n b A$ gene. A promoter-like sequence was identified in the left-hand end of the closely related transposon Tn916 (Clewell et al., 1988). This sequence is conserved in Tn918 (Fig. 4) and may allow a low level of expression of FnBPA in the mutant. The intense band of about $50 \mathrm{kDa}$ was protein $\mathrm{A}$ which bound the peroxidase-conjugated anti-fibronectin antibody. Similar results were obtained with the spectinomycin-resistant derivatives 879R4SSp and 879R4SSp/1436 (data not shown).

\section{Defective attachment of the low-fibronectin-binding mutant to surface-bound fibronectin}

Adhesion of the parental strain S. aureus $879 \mathrm{R} 4 \mathrm{~S}$ was linearly promoted by low amounts $(<50 \mathrm{ng}$ per coverslip) of fibronectin immobilized on PMMA surfaces, then increased marginally at higher amounts of immobilized fibronectin (Fig. 6). At all concentrations of fibronectin, the low-fibronectin-binding mutant 879RS/ 1536 showed a markedly decreased, but still significant, attachment compared to the parental strain. In contrast the double $f n b A$ fnbB mutant of $8325-4$ was completely defective (Greene et al., 1995). Similar results were obtained with the spectinomycin-resistant derivatives 879R4SSp and 879R4SSp/1436 (data not shown).

\section{DISCUSSION}

S. aureus strains 8325-4 and Newman express two FnBPs encoded by separately transcribed fnb genes. Data presented here suggest that $S$. aureus $879 \mathrm{R} 4 \mathrm{~S}$ has only one gene which is closely related to $f n b A$ of strain $8325-4$. 


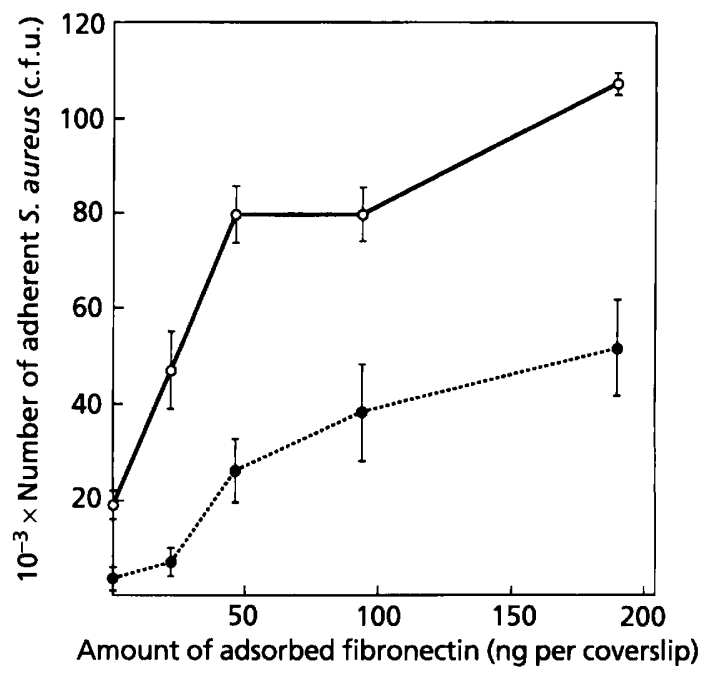

Fig. 6. In vitro adhesion of $S$. aureus strain $879 R 4 S(O)$ and the low-fibronectin-binding mutant 879R4S/1536 (O) to gelatinPMMA coverslips coated with human fibronectin. Mean values are shown $\pm \operatorname{SEM}(n=3)$.

The low-fibronectin-binding mutant $879 \mathrm{R} 4 \mathrm{SSp} / 1536$ has a copy of transposon $\operatorname{Tn} 918$ inserted between the promoter and coding sequence of its $f n b A$ gene. The $f n b A$ gene of strain $879 \mathrm{R} 4 \mathrm{~S}$ is almost $97 \%$ identical to $f n b A$ of $8325-4$ in the 237 bp of the coding sequence and the 41 bp of $5^{\prime}$ non-coding sequence. Conserved PstI and EcoRI sites are located in this region. Given the similarity of coding and $5^{\prime}$ non-coding sequences, the 879R4S fnb $A$ promoter is likely to be the same as that of 8325-4 fnb $A$. The promoter was mapped by primer extension between bases -85 and -57 (Greene et al., 1995). The insertion site of $\operatorname{Tn} 918$ is between bases -41 and -42 and is thus situated between the promoter and coding sequence of the $f n b A$ gene. This is consistent with reduced adherence to fibronectin-coated PMMA coverslips and to the reduced levels of FnBPA detected by Western ligand affinity blotting. A potential promoter is located at the right-hand end of $\operatorname{Tn} 918$ (Clewell et al., 1988) (Fig. 4). This is not likely to be a strong promoter as the spacing between the -35 and -10 regions is $18 \mathrm{bp}$, which is not optimal for high-level expression, and there are several differences from the consensus $E$. coli promoter sequence (Hawley \& McClure, 1983). Nevertheless, it may be active enough to enable low-level transcription of the $f n b A$ gene of 879R4S/1536. This might explain the low-level expression of the FnBP and the reduced, but still significant, adherence of the mutant.

The use of transposon mutagenesis to make fibronectinbinding-defective mutants was successful in the case of $S$. aureus $879 \mathrm{R} 4 \mathrm{~S}$ because there is only one fnb gene. This approach is unlikely to have worked with $S$. aureus $8325-$ 4 because this strain has two $f n b$ genes which are transcribed independently. The two fnb genes encode distinct FnBPs and both must be inactivated to abolish the ability of $8325-4$ to bind to fibronectin-coated surfaces
(Greene et al., 1995). Tn918 mutagenesis would not abrogate expression of two fnb genes unless the insertion caused an adjacent deletion to inactivate both genes.

Many studies have shown that $S$. aureus binds to fibronectin in vitro (Maxe et al., 1987; Raja et al., 1990; Greene et al., 1995). However it is not clear if this is an important factor in the initiation of staphylococcal infections. Fibronectin is a component of the many host proteins deposited on the surface of implanted biomaterials. Adherence assays using biomaterials explanted from human patients showed fibronectin to be active in promoting attachment of $S$. aureus ((Vaudaux et al., 1989, 1993). Also, a mutant of $S$. aureus $8325-4$ defective in fibronectin-binding did not bind to PMMA coverslips that had been removed from a subcutaneously implanted tissue cage implying that a significant quantity of fibronectin had been deposited in vivo (Greene et al., 1995). This suggests that fibronectin is an important component of the host proteins coating an implant and may be responsible for promoting bacterial attachment in vivo.

A rat endocarditis model was used by Kuypers \& Proctor (1989) to examine the role of fibronectin in the initiation of infection. Cardiac endothelial trauma was produced in rats by inserting a catheter into the left ventricle (Santoro \& Levison, 1978). Animals were challenged with S. aureus $879 \mathrm{R} 4 \mathrm{SSp}$ or the low-fibronectin-binding mutant $879 R 4 S S p / 1536$. Colonization of the left side of the heart of rats challenged with strain 879 R4SSp/1536 was 250 fold lower than in rats challenged with the wild-type strain.

A mutant of $S$. aureus Newman defective in the fibrinogenbinding protein clumping factor also exhibited reduced virulence in the rat endocarditis model (Moreillon et al., 1995). This suggests that adherence to cardiac vegetations is multifactorial. We are currently testing this by measuring the virulence of a null mutant of 8325-4 lacking $f n b A$ and $f n b B$, and a mutant lacking both fibronectin- and fibrinogen-binding proteins.

\section{ACKNOWLEDGEMENTS}

This work was supported by the Health Research Board of Ireland, by The Wellcome Trust (project grant 033403), by the Swiss National Foundation (grants 32-30161 and 5002-35180), by Ohmeda (Swindon), by the US National Institute of Health (HL-29586) and by the Graduate and Medical School Department of Medicine, University of Wisconsin. We thank Manuela Bento for technical assistance.

\section{REFERENCES}

Ausubel, F. M., Brent, R., Kingston, R. E., Moore, D. D., Smith, J. A., Seidman, J. J. \& Struhl, K. (1987). Current Protocols in Molecular Biology. New York: John Wiley.

Boden, M. K. \& Flock, J.-I. (1989). Fibrinogen-binding protein/ clumping factor from Staphylococcus aureus. Infect Immun 57, 2358-2363.

Bozzini, S., Visai, L., Pignatti, P., Petersen, T. E. \& Speziale, P. (1992). Multiple binding sites in fibronectin and the staphylococcal fibronectin receptor. Eur J Biochem 207, 327-333. 
Chhatwal, G. S., Preissner, K. T., Muller-Berghaus, G. \& Blobel, H. (1987). Specific binding of the human $S$ protein (vitronectin) to streptococci, Staphylococcus aureus, and Escherichia coli. Infect Immun 55, 1878-1883.

Clewell, D. B., An, F. Y., White, B. A. \& Gawron-Burke, C. (1985). Streptococcus faecalis sex pheromone (cAM373) also produced by Stapbylococcus aureus and identification of a conjugative transposon (Tn918). J Bacteriol 162, 1212-1220.

Clewell, D. B., Flannagan, S. E., Ike, Y., Jones, J. M. \& GawronBurke, C. (1988). Sequence analysis of termini of conjugative transposon Tn916. J Bacteriol 170, 3046-3052.

Greene, C., McDevitt, D., Francois, P., Vaudaux, P., Lew, D. P. 8 Foster, T. J. (1995). Adhesion properties of mutants of Stapbylococcus aureus defective in fibronectin-binding proteins and studies on expression of $f n b$ genes. Mol Microbiol 17, 1143-1152.

Hanski, E. \& Caparon, M. G. (1992). Protein F, a fibronectinbinding protein, is an adhesin of the group A streptococcus Streptococcus pyogenes. Proc Natl Acad Sci US A 89, 6172-6176.

Hawley, D. K. \& McClure, W. R. (1983). Compilation and analysis of Escherichia coli promoter sequences. Nucleic Acids Res 11, 2237-2255.

Holderbaum, D., Spech, T., Ehrhart, L. A., Keys, T. \& Hall, G. 5. (1987). Collagen binding in clinical isolates of Staphylococcus aureus. J Clin Microbiol 25, 2258-2261.

Jonsson, K., Signas, C., Muller, H.-P. \& Lindberg, M. (1991). Two different genes encode fibronectin-binding proteins in Stapbylococcus aureus. The complete nucleotide sequence and characterization of the second gene. Eur J Biochem 202, 1041-1048.

Kuypers, J. M. \& Proctor, R. A. (1989). Reduced adherence to traumatized rat heart valves by a low-fibronectin-binding mutant of Stapbylococcus aureus. Infect Immun 57, 2306-2312.

Laemmli, U. K. (1970). Cleavage of structural proteins during the assembly of the head of bacteriophage T4. Nature 227, 680-685.

Lindberg, M., Sjostrom, J. E. \& Johansson, J. (1972). Transformation of chromosomal and plasmid characters in Stapbylococcus aurews. I Bacteriol 109, 844-847.

Lindgren, P.-E., Speziale, P., McGavin, M., Monstein, H. J., Hook, M., Visai, L., Kostiainen, T., Bozzini, S. \& Lindberg, M. (1992). Cloning and expression of two different genes from Streptococcus dysgalactiae encoding fibronectin receptors. I Biol Chem 267, 1924-1931.

Lopes, J. D., dos Reis, M. \& Brentani, R. R. (1985). Presence of laminin receptors in Stapbylococcus aureus. Science 229, 275-277.

McDevitt, D., Francois, P., Vaudaux, P. \& Foster, T. J. (1994). Molecular characterization of the fibrinogen receptor (clumping factor) of Stapbylococcus aureus. Mol Microbiol 11, 237-248.

McGavin, M. J., Raucci, G., Gurusiddappa, S. \& Hook, M. (1991). Fibronectin-binding determinants of the Staphylococcus aureus fibronectin receptor. I Biol Cbem 266, 8343-8347.

McGavin, M. J., Gurusiddappa, S., Lindgren, P.-E., Lindberg, M., Raucci, G. \& Hook, M. (1993). Fibronectin receptors from Streptococcus dysgalactiae and Stapbylococcus aureus. Involvement of conserved residues in ligand binding. J Biol Cbem 268, 23946-23953.

Maxe, I., Ryden, C., Wadstrom, T. \& Rubin, K. (1987). Specific attachment of Staphylococcus aureus to immobilized fibronectin. Infect Immun 54, 695-704.

Miller, J. H. (1972). Experiments in Molecular Genetics. Cold Spring Harbor, NY : Cold Spring Harbor Laboratory Press.
Moreillon, P., Entenza, J. M., Francioli, P., McDevitt, D., Foster, T. J., Francois, P. \& Vaudaux, P. (1995). Role of Staphylococcus aureus coagulase and clumping factor in the pathogenesis of experimental endocarditis. Infect Immun 63, 4738-4743.

Navarre, W. W. \& Schneewind, O. (1994). Proteolytic cleavage and cell wall anchoring at the LPXTG motif of surface proteins in Gram positive bacteria. Mol Microbiol 14, 115-121.

Novick, R. P. (1963). Properties of a cryptic high-frequency transducing phage in Stapbylococcus aureus. Virology 33, 155-166.

Raja, R. H., Raucci, G. \& Hook, M. (1990). Peptide analogs to a fibronectin receptor inhibit attachment of Stapbylococcus aureus to fibronectin-coated substrates. Infect Immun 58, 2593-2598.

Sambrook, J., Fritsch, E. F. \& Maniatis, T. (1989). Molecular Cloning: a Laboratory Manual, 2nd edn. Cold Spring Harbor, NY: Cold Spring Harbor Laboratory Press.

Santoro, J. \& Levison, M. W. (1978). Rat model of experimental endocarditis. Infect Immun 19, 915-918.

Schneewind, O., Mihaylova-Petkov, D. \& Model, P. (1993). Cell wall sorting signals in surface proteins of Gram-positive bacteria. EMBO J 12, 4803-4811.

Signas, C., Raucci, G., Jonsson, K., Lindgren, P.-E., Anantharamaiah, G. M., Hook, M. \& Lindberg, M. (1989). Nucleotide sequence of the gene for a fibronectin-binding protein from Staphylococcus aureus: use of this peptide sequence in the synthesis of biologically active peptides. Proc Natl Acad Sci USA 86, 699-703

Southern, E. M. (1975). Detection of specific sequences among DNA fragments separated by gel electrophoresis. I Mol Biol 98, 503-517.

Speziale, P., Raucci, G., Visai, L., Switalski, L. M., Timpl, R. \& Hook, M. (1986). Binding of collagen to Stapbylococcus aureus Cowan 1. J Bacteriol 167, 77-81.

Vaudaux, P., Waldvogel, F. A., Morgenthaler, J. J. \& Nydegger, U. E. (1984). Adsorption of fibronectin onto polymethylmethacrylate and promotion of Stapbylococcus aureus adhesion. Infect Immun 45, 768-774.

Vaudaux, P., Pittet, D., Haeberli, A., Huggler, E., Nydegger, U. E., Lew, D. P., \& Waldvogel, F. A. (1989). Host factors selectively increase staphylococcal adherence on inserted catheters: a role for fibronectin and fibrinogen or fibrin. $J$ Infect Dis 160, 865-875.

Vaudaux, P., Pittet, D., Haeberli, A., Lerch, P. G., Morgenthaler, J. J., Proctor, R. A., Waldvogel, F. A. \& Lew, D. P. (1993). Fibronectin is more active than fibrin or fibrinogen in promoting Stapbylococcus aureus adherence to inserted intravascular devices. I Infect Dis 167, 633-641.

Vaudaux, P. E., Francois, P., Proctor, R. A., McDevitt, D., Foster, T. J., Albrecht, R. M., Lew, D. P., Wabers, H. \& Cooper, S. L. (1995). Use of adhesion-defective mutants of Stapbylococcus aureus to define the role of specific plasma proteins in promoting bacterial adhesion to canine arteriovenous shunts. Infect Immun 63, 585-590.

Yanisch-Perron, C., Vieira, J. \& Messing, J. (1985). Improved M13 phage cloning vectors and host strains: nucleotide sequences of the M13mp18 and pUC19 vectors. Gene 33, 103-119.

Received 10 November 1995; revised 8 March 1996; accepted 13 March 1996. 